\title{
Review of the Rice Blast Diseases (Pyricularia Oryzae) Response to Nitrogen and Silicon Fertilizers
}

\author{
Desalegn Yalew Fetene* \\ Ethiopian Institute of Agricultural Research, Fogera National Rice Research and Training Center; P. O. Box \\ 1937, Bahir Dar, Ethiopia. \\ *Corresponding Author: Desalegn Yalew Fetene, Ethiopian Institute of Agricultural Research, Fogera \\ National Rice Research and Training Center; P. O. Box 1937, Bahir Dar, Ethiopia.
}

\begin{abstract}
The rice blast disease, caused by a fungus Pyricularia oryzae (Cavara), is a worldwide problem in rice and is dangerous because of its yield loss potential ranging up to $100 \%$ under favourable conditions. Blast development is favoured by thick stands and high nitrogen rates which increase canopy thickness. With this in mind it indicated that some fertilizer application may have a negative or positive response of plants toward the disease. High rate of nitrogen fertilization has been found to increase the severity of the rice blast disease to a great extent as compared to the low nitrogen rate. In contrast, high rate of silicon fertilization reduces the severity of the disease and vice versa. Therefore, nutrition management is one of the most important practices for high production system that may affect response of rice to blast disease.
\end{abstract}

Keywords: Rice, nitrogen fertilizer rate, silicon fertilize rate, disease, blast, severity

\section{INTRODUCTION}

Rice blast is a worldwide problem in rice and is dangerous because of its yield loss potential ranging up to $100 \%$ under favorable conditions (Luo et al., 1998; Netam et al., 2011). The disease is generally considered the most important worldwide disease in all the rice growing regions of the world and has been reported in more than 85 countries (Rao, 1994). It is also the most important fungal disease in both upland and lowland rice (Bonman et al., 1991; Lee, 1994).

Blast can infect rice from the seedling stage through maturity and can cause complete loss of seedling in seedbed and epidemic in the field. Infection results in lesions on most of the plant including leaves, leaf collar, stems, and nodes, internodal parts of culms, panicles and grain. Although $P$. oryzae infect all foliar tissues, infection of the panicle can lead to complete loss of grain. The disease may also called leaf blast, collar rot, node blast panicle blast or rotten neck blast depending on the portion of the rice plant infected (Zeigler et al., 1994; Thurston, 1998; Webster, 2000). Symptoms develop on all above ground plant parts. Lesions or spots are the most common symptom, which are usually 1-1.5 $\mathrm{cm}$ long and 0.3-0.5 $\mathrm{cm}$ wide (NSW, 2012).

Rice blast epidemics are often more severe in temperate and subtropical ecosystems, especially when effective management strategies are not implemented (Bhat et al., 2013). Losses due to blast include severe reductions in yield, milling, and the cost of applying fungicides. Unlike most rice diseases blast is very explosive and can completely destroy a crop in a very short time (Groth and Hollier, nd). The severity of the damage depends on the part of the plant affected and on the cultivar. Leaf infection reduces photosynthetic area and may eventually result in plant death. Panicle infection reduces yield and therefore this involves important economic losses (Roumen, 1992).

Blast epidemics are mainly dependent on climatic conditions, crop management practices, such as nitrogen inputs or water supply, and cultivar susceptibility (Nyvall, 1999). Despite the positive role played by nutrition in control of diseases, some farming practices may cause nutrition imbalances resulting to disease development (Magdoff et al., 2000). Webster and Gunell (1992) reported that excess nitrogen encourages disease and this enhances the increase of inoculums levels. On the contrary Hoffland et al. (1999) and Snoeijers et al. (2000) observed that low nitrogen also led to disease increase resulting from weak plants that lacked sufficient defence against disease. Therefore, 
the objective of this paper is to review the response of rice blast diseases to nitrogen fertilizer application rate.

\section{LITERATURE REVIEW}

\subsection{Biology of the Pathogen and Diseases Development}

The rice blast disease is caused by a fungus Pyricularia oryzae (Cavara) (synonym: Pyricularia grisea) (Cook) Sacc., anamorph of Magnaporthe grisea (Hebert) Barr. (Synonym: Magnaporthe oryzae) (Webster and Gunnell, 1992; Zhou et al., 2007). It is filamentous ascomycetes that can reproduce both sexually and asexually. Sexual reproduction occurs when two strains of opposite mating types meet to form a fruiting structure known as perithecium in which ascospores is formed (Dean et al., 2005). The asexual life cycle begins when the hyphae of the fungus produces fruiting structures and sporulates to give conidia, which measure 20-22 x 10-12 $\mu \mathrm{m}, 2$-septate, translucent, and slightly darkened.

The fungus infects the plant by the spore germinating and forming an apperssorium (a thick fungal cell) on the plant surface and then exerting a haustoria (feeding structure) into the plant cells. When the spores land on leaves and other aerials tissues of susceptible plant, they germinate and develop the appressorium which penetrate the plant cell by producing a penetration peg. Pressure in the appressorium increases and the structure explodes forcing the penetration through the cell wall and into the cell (Dean et al., 2005). The fungus grows hyphae inter or intracellular within the leaf and form lesions. The initial infections occur on leaves usually around tillering and appear as diamond, football, or spindle shape lesion with pointed ends. Once it is established in the host plant the fungal hyphae sporulates and produce asexual spores (Kim, 1994). The pathogen completes its life cycle within one week. Each of the phases (sporulation, releases, germination and the penetration) play an important role during the blast epidemic and requires different environments.

Sporulation phase is the first step that facilitate in building up the leaf blast epidemic as it provides the inoculum population (Webster and Gunnell 1992; Kim, 1994). The leaf blast phase occurs mostly between the seedling and late tillering stages. Lesions start as small water soaked areas on young leaves and enlarge quickly, under moist warm conditions, into diamond shape with a blue gray cast which are the fungal spores. However, under natural conditions, sporulation is greatly affected by the age of the crop and the size of the lesion together with the variety of rice (Kim, 1994). In case of sever or multiple infections, lesions may coalesce covering most of the leaf blast (Groth and Hollier, nd).

\subsection{Favourable Conditions and Disease Transmission}

Pyricularia oryzae is favoured by moist warm conditions (long dew periods ( 9 plus hours) increased by fog, shade or frequent light rains). Moreover, a minimum of $8 \mathrm{hrs}$ moisture is needed for infection to occur. Blast development is favoured by thick stands and high nitrogen rates which increase canopy thickness resulting in higher moisture levels but is most severe under upland or drained conditions. The fungus produces many spores, on stalk like structures called sporangia, in the presence of a favourable environment and a susceptible host and causes numerous new infections in the field and neighbouring fields. The spores are carried by wind and water over long distances. Other conditions that favour blast are sandy soils and fields lined with trees (Groth and Hollier, nd).

In addition, draining of water allows the formation of nitrates resulting to drought stress. According to Kato et al. (2004) rice is more susceptible to drought than other cereals due to its inability to regulate its transpiration water loss a weakness that may be accelerated by rice blast attack. In contrast, water seeding (planting on very wet soil) is recommended as this will reduce the transmission of disease from the seed to the seedling. As reported by Manandhar et al. (1998), water management through flooding is also recommended to reduce rice blast unlike when there is water stress.

The pathogen can continue to live in plants from one crop season to another in the tropics, or survive in the temperate zone on crop residues of diseased plants, or on ratoon (Zeigler et al., 1994). Seed as secondary hosts also have been reported as possible sources of primary inoculum (Lee and Dean, 1993). The pathogen overwinters as spores in infected plant debris. The fungus produces new spores in the spring that reinfects rice. Spores are carried by wind and splashing rain. Movement can be over long distances (Groth and Hollier, nd).

\subsection{Management of Rice Blast Disease}

There are several control strategies that may be undertaken in management of rice blast, these may include chemical control, nutrition management, cultural practices and use of resistant varieties. 


\subsubsection{Nutrition Management}

The understanding of impacts of nutrition management on interactions between rice and diseases is a base to stimulate high yield production system (Luong et al., 2003). In this view Magdoff et al. (2000) indicated that nutrition management is one of the most important practices for high production system that may affect response of rice to diseases, as well as developmental pattern of the disease populations due to the change of environments. Indeed, most disease management methods used by farmers can be considered as soil fertility management strategies (Magdoff et al., 2000). Increasingly, recent research is showing that the ability of a crop plant to resist or tolerate insect pests and diseases is tied to optimal physical, chemical and mainly biological properties of soils (Luong et al., 2003).

According to Luong et al. (2003) soils with high organic matter and high biological activity generally exhibit good soil fertility as well as complex food webs and beneficial organisms that prevent infection. With this in mind it indicated that some fertilizer application may have a negative or positive response of plants toward the disease. For instance, excess nitrogen encourages disease hence overlap must be avoided since this enhances the increase of inoculum levels (Webster and Gunell, 1992). Therefore, despite the positive role played by nutrition in control of diseases, some farming practices may cause nutrition imbalances resulting to disease development (Magdoff et al., 2000). Meyer (2000) also indicated that soil fertility practices have impact on the physiological susceptibility of crop plants to insect pests and diseases either affecting the resistance of individual plant positively or negatively. On the other hand, though excess nitrogen encourages disease, split application of nitrogen $(\mathrm{N})$ in upland rice was found to decrease the rice blast as compared to a single application in furrow at planting (Kurschner et al., 1992).

\subsubsection{Silicon}

Silicon ( $\mathrm{Si}$ ) is known as a "beneficial element" for plants. The direct and indirect benefits of the element for crops especially grasses are related to resistance to diseases, insect pests, and drought. Plant species are considered Si accumulators when the concentration of Si (in dry weight basis) is greater than $1 \mathrm{~g} / \mathrm{kg}$ (Epstein, 1999). Dry land grasses such as wheat, oat, rye, barley, sorghum, corn, and sugarcane contain about $10 \mathrm{~g} / \mathrm{kg}$ in their biomass, while aquatic grasses have Si contents of up to $50 \mathrm{~g} / \mathrm{kg}$ (Korndorfer et al., 2001). In rice, Si accumulation is about $108 \%$ greater than that of nitrogen while the concentrations between 3 and 5\% may be the minimum tissue levels needed for disease control (Datnoff et al., 1997). It is estimated that a rice crop producing a total grain yield of 5000 $\mathrm{kg} / \mathrm{ha}$ will remove Si at 230 to $470 \mathrm{~kg} / \mathrm{ha}$ from the soil (Savant et al., 1997).

In the absence of adequate silica, brown spot disease (Bipolaris oryzae) was often found to be very severe giving rice an overall brownish appearance. Neck rot (Pyricularia oryzae) too increased in the rice field that contained inadequate silicon (Datnoff et al., 1990; Datnoff et al., 2001). Low Si uptake was also seen to increase the susceptibility of rice to blast and other diseases (Kobayashi et al., 2001; Rodrigues et al., 2001; Massey and Hartley, 2006).

For plants disease resistance, epidermal cell walls of silicon accumulators are impregnated with a firm layer of silica and become effective barriers against water loss and fungal growth thereby preventing formation of haustoria and hyphal penetration (Marschner, 1995). The function of silicon deposition in the defense mechanism may be similar to that of enhanced synthesis of polyphenols and lignin at the site of infection (Vance et al., 1980). The phenolics play a role as either phytoalexins or as precursors of lignin and suberin biosynthesis. Silicon can also be associated with lignin-carbohydrate complexes in the cell wall of rice epidermal cells (Inanaga, 1995). In addition, the leaves and culms of rice plants, grown in the presence of silicon showed an erect growth that greatly improved the distribution of light within the canopy. This avoided the shading that would otherwise encourage a suitable environment for survival of the pathogens (Ma and Takahashi, 1991).

Seebold et al. (2001) noted a reduction in number of the sporulating lesions on partially resistant and susceptible rice cultivars fertilized with calcium silicate indicating fewer successful infections per unit of inoculum. Similarly, Prabhu et al. (2001) found that rice cultivar that accumulated more silicon on the shoots showed less incidence of rice blast. Experimental result conducted by Seebold et al. (2000) using blast resistant, partially resistant, and susceptible cultivars of rice planted in soil amended with $\mathrm{Si}$ at 0,500 , or $1,000 \mathrm{~kg} / \mathrm{ha}$, showed that the interaction between rate of $\mathrm{Si}$ and rice cultivar was significant $(\mathrm{P} \leq 0.05)$. The application of $\mathrm{Si}$ at 500 and $1,000 \mathrm{~kg} /$ ha significantly reduced severity of leaf blast from 1.8 to $0.5 \%$ on Linea $2 \mathrm{SR}$ and from 5.9 to $1.6 \%$ on Oryzica 1 as compared to these cultivars without Si. 
Table1. Severity of leaf blast and neck blast on blast-resistant, partially resistant, and blast-susceptible cultivars of rice treated with Si at 500 or $1,000 \mathrm{~kg} / \mathrm{ha}$

\begin{tabular}{|c|c|c|c|c|c|c|}
\hline \multirow{2}{*}{$\begin{array}{c}\text { Silicon } \\
\text { rate } \\
\text { kg/ha }\end{array}$} & \multicolumn{2}{|c|}{ Leaf blast severity \% on each rice variety } & \multicolumn{3}{c|}{ Neck blast severity \% on each rice variety } \\
\cline { 2 - 7 } & Oryzica Lilanos 5 & Linea 2SR & Oryzica 1 & Oryzica Lilanos 5 & Linea 2SR & Oryzica 1 \\
\hline 0 & $0.06 \mathrm{a}$ & $1.8 \mathrm{a}$ & $5.9 \mathrm{a}$ & $2.8 \mathrm{a}$ & $33.0 \mathrm{a}$ & $55.1 \mathrm{a}$ \\
\hline 500 & $0.04 \mathrm{a}$ & $0.8 \mathrm{ab}$ & $3.0 \mathrm{~b}$ & $4.4 \mathrm{a}$ & $28.0 \mathrm{a}$ & $48.7 \mathrm{a}$ \\
\hline 1000 & $0.01 \mathrm{a}$ & $0.5 \mathrm{~b}$ & $1.6 \mathrm{~b}$ & $2.4 \mathrm{a}$ & $20.5 \mathrm{a}$ & $39.4 \mathrm{a}$ \\
\hline
\end{tabular}

a column followed by the same letter do not differ significantly according to Fisher's protected least significantdifference test (FLSD) $(\mathrm{P} \leq 0.05)$

Source: Seebold et al. (2000)

\subsubsection{Nitrogen}

Nitrogen is essential for plant growth and development and is usually a limiting factor for high productivity. Cereal crops obtain nitrogen from the soil as nitrates or ammonia while legumes get through nitrogen fixation (Lea et al., 2007). Nitrogen influences the branching, tillering and in leaf expansion which determines the size of canopy produced. However, Kim and Kim (1990), Cloud and Lee (1993) and Ishiguro (1994) found that excessive growth due to unbalanced nitrogen supply creates microclimate conditions favourable to fungal diseases. This is accelerated by lodging of cereals that are over-supplied with nitrogen and have inadequate potash. Humidity remains higher in lodged crops creating a microclimatic that provides ideal conditions for spores' germination and survival of the fungi. According to Leitch and Jenkinss (1995); Tiedemann (1996), and Solomon et al. (2003), high leaf nitrogen concentration increases the growth of fungus.

Similarly, in rice, among several factors which influence the occurrence and severity of blast, rate of nitrogen fertilization has been found to affect the severity of the disease to a great extent (Kapoor and Sood, 2000). The increase in blast severity with the increase in rate of nitrogen application has been reported by many workers (Kapoor and Sood, 2000; Long et al. 2000) and has been attributed to increased plant transpiration by the increase in leaf area index which thereby increases the susceptibility of host tissue. Work done by Robert et al. (2005) indicated that when nitrogen in the wheat and rice plant was applied in limited quantities, production of spore of leaf rust was reduced. Jensen and Munk (1997) and Long et al. (2000) found an increase in blast lesion when the level of nitrogen was applied above the recommended rate. Similar findings were found by Kurschner et al. (1992) who reported that while nitrogen was essential for productivity, the severity of blast also increased with higher rate of application which increases metabolism in rice plant resulting to tissue susceptibility to rice blast.

At heading and during grain filling stages of the rice plant nitrogenous compounds may increase, decrease or cease, depending on the environmental conditions, cultivar, and/or nitrogen fertilizer rate of which may influence rice blast incidence (Wilson et al.,1990; Norman et al., 1992). Bastiaans, (1993) reported that rice blast disease reduced nitrogen uptake before flowering and increased relative contribution of the stem to the overall nitrogen reallocation during the grain filling stage. Other studies by Koutroubas et al. (2008) showed that when rice plant is inoculated with blast fungus, nitrogen utilization efficiency for both yield and biomass production was reduced. In addition, Hardter, (1997) summarized the inverse relationship between plant nutrition of $\mathrm{K}$ and disease incidence of rice blast (Piricularia oryzae), that generally occurs at high nitrogen $(\mathrm{N})$ supply in soils poor in $\mathrm{K}$.

In an experiment conducted by Bhat et al. (2013) to assess the effect of nitrogen application and fungicidal sprays on rice blast disease using local popular susceptible variety (K-448) and resistant variety (Shalimar Rice-1), revealed that the increase in amount of nitrogen application in Jehlum significantly increases the leaf and neck blast. Leaf and neck blast control of 19.6 and $15.6 \%$, respectively, was achieved by using recommended dose of nitrogen as against higher dose of nitrogen. However, blast severity on resistant variety (Shalimar Rice-1) was not significantly affected by rate of 
nitrogen fertilization. Leaf and neck blast control of 95.7 and 100\%, respectively, was registered by using resistant variety alone for blast control.

Table2. Effect of rate of nitrogen fertilization and number of fungicidal sprays on blast disease and yield of rice

\begin{tabular}{|c|c|c|c|c|c|c|}
\hline Treatments & $\begin{array}{c}\text { Leaf } \\
\text { blast } \\
\text { severity } \\
\%\end{array}$ & $\begin{array}{l}\text { Disease } \\
\text { control } \\
\%\end{array}$ & $\begin{array}{l}\text { Neck blast } \\
\text { incidence } \\
\%\end{array}$ & $\begin{array}{l}\text { Disease } \\
\text { control } \\
\%\end{array}$ & $\begin{array}{l}\text { Grain } \\
\text { yield } \\
\text { Q/ha }\end{array}$ & $\begin{array}{l}\text { Increase } \\
\text { in yield } \\
\%\end{array}$ \\
\hline $\begin{array}{c}\text { Resistant variety (Shalimar } \\
\text { Rice-1) + } 120 \mathrm{~kg} \mathrm{~N}\end{array}$ & $\begin{array}{c}1.1 \\
(1.0)\end{array}$ & 95.7 & $\begin{array}{c}0.0 \\
(0.0)\end{array}$ & 100.0 & 64.6 & 19.2 \\
\hline $\begin{array}{c}\text { Resistant variety (Shalimar } \\
\text { Rice-1) + 150 kg N }\end{array}$ & $\begin{array}{c}1.2 \\
(1.1)\end{array}$ & 95.3 & $\begin{array}{c}0.0 \\
(0.0)\end{array}$ & 100.0 & 64.2 & 18.4 \\
\hline $\begin{array}{c}\text { Susceptible variety (Jehlum) } \\
+120 \mathrm{~kg} \mathrm{~N}\end{array}$ & $\begin{array}{l}20.5 \\
(4.5)\end{array}$ & 19.6 & $\begin{array}{l}14.1 \\
(3.6) \\
\end{array}$ & 15.6 & 55.7 & 2.7 \\
\hline $\begin{array}{c}\text { Susceptible variety (Jehlum)+ } 120 \mathrm{~kg} \\
\mathrm{~N}+\text { single } \\
\text { spray of Tricyclazole } 75 \text { WP @ } \\
0.06 \%\end{array}$ & $\begin{array}{l}13.0 \\
(3.6)\end{array}$ & 49.4 & $\begin{array}{c}8.2 \\
(2.7)\end{array}$ & 50.9 & 59.4 & 9.5 \\
\hline $\begin{array}{c}\text { Susceptible variety (Jehlum) }+120 \\
\text { kg N+ need based } \\
\text { sprays of Tricyclazole 75WP } \\
\text { @ } 0.06 \%\end{array}$ & $\begin{array}{l}3.7 \\
(1.9)\end{array}$ & 85.5 & $\begin{array}{l}1.5 \\
(1.2)\end{array}$ & 91.0 & 62.8 & 15.8 \\
\hline $\begin{array}{c}\text { Susceptible variety (Jehlum) }+150 \\
\text { kg N }+ \text { Single spray of } \\
\text { Tricyclazole } 75 \text { WP @ } 0.06 \%\end{array}$ & $\begin{array}{l}18.7 \\
(4.3)\end{array}$ & 26.7 & $\begin{array}{l}12.8 \\
(3.4)\end{array}$ & 23.4 & 56.5 & 4.2 \\
\hline $\begin{array}{l}\text { Susceptible variety (Jehlum) }+150 \\
\text { kg N+ need based } \\
\text { sprays of Tricyclazole } 75 \mathrm{WP}(.06 \%\end{array}$ & $\begin{array}{c}8.4 \\
(2.8)\end{array}$ & 67.5 & $\begin{array}{c}3.7 \\
(1.8)\end{array}$ & 77.8 & 62.2 & 3.1 \\
\hline $\begin{array}{l}\text { Susceptible variety (Jehlum) } \\
+150 \mathrm{~kg} \mathrm{~N} \text { (check) }\end{array}$ & $\begin{array}{l}25.5 \\
(5.0)\end{array}$ & - & $\begin{array}{l}16.7 \\
(4.0)\end{array}$ & - & 54.2 & - \\
\hline C.D at $5 \%$ & 0.2 & & 0.3 & & 0.37 & \\
\hline
\end{tabular}

*Figures in parentheses are square root transformed values

Source: Bhat et.al. (2013)

\section{SUMMARY AND CONCLUSION}

The rice blast disease, caused by a fungus Pyricularia oryzae (Cavara), is a worldwide problem in rice and is dangerous because of its yield loss potential ranging up to $100 \%$ under favourable conditions. The disease is generally considered the most important worldwide disease in all the rice growing regions of the world and has been reported in more than 85 countries both in upland and low land rice. Blast epidemics are mainly dependent on climatic conditions, crop management practices, such as nitrogen inputs or water supply, and cultivar susceptibility. Moreover, the rice blast disease development is favoured by thick stands, very low Silicon and high nitrogen rates which increase canopy thickness resulting in higher moisture levels but is most severe under upland or drained conditions. On other hands, the diseases could be managed through proper application of Silicon fertilizer, avoiding of excess nitrogen fertilizer, planting on very wet soil and flooding. Therefore, rice growers can manage the disease by using these methods.

\section{REFERENCES}

[1] Bastiaans, L. 1993. Effects of leaf blast on growth and production of a rice crop. Determining the mechanism of yield reduction. Netherlands Journal of Plant Pathology, 99: 323-334.

[2] Bhat, Z.A., Ahangar, M.A., Sanghera, G.S. and Mubarak, T. 2013. Effect of Cultivar, Fungicide Spray and Nitrogen Fertilization on Management of Rice Blast Under Temperate Ecosystem. International Journal of Science, Environment and Technology, 2 (3): 410 - 415.

[3] Bonman, J.M., Estrada, B.A., Kim, C.K., Ra, D.S., Lee E.J. 1991. Assessment of blast disease and yield loss in susceptible and partially resistant rice cultivars in two irrigated lowland environments. Plant Disease, 75: 462-466.

[4] Cloud, G. L. and Lee, F.N. 1993. Rice blast: Factors influencing severity and control strategies used to manage the disease. Arkansas Cooperative Extension Service, Misc. Publication. 341P. 
[5] Datnoff, L.E., Snyder, G.H. and Jones, D.B 1990. Influence of calcium silicate slag and fungicides on brown spot and neck rot development and yield of rice, 2: 26-33.

[6] Datnoff, L. E., Deren, C.W. and Snyder, G.H. 1997. Silicon fertilization for disease management of rice in Florida. Crop Protection, 16: 525-531.

[7] Datnoff, L.E., Snyder, G.H. and Korndorfer, G.H. 2001. Silicon in Agriculture. Elsevier Science. Amsterdam, the Netherlands. Pp. 403.

[8] Dean, R.A., Talbot, N.J., Ebbole, D.J., Farman, M.L., Mitchell, T.K., Orbach, M.J., Thon,M., Kulkarni, R., Xu, J.R., Pan, H., Read, N.D., Lee, Y.H., Carbone, I., Brown, D.Oh, Y.Y., Donofrio, N., Jeong, J.S., Soanes, D.M., Djonovic, S., Kolomiets, E.,Renmeyer, C., Li, W., Harding, M., Kim, S., Lebrun, M.H., Bohnert, H., Coughlan,S., Butler, J., Calvo, S., Li-Jun, M., Nicol, R., Purcell, S., Nusbaum, C., Galagan,J.E., and Birren, B.W. 2005. The genome sequence of the rice blast fungus Magnaporthe grisea. Nature 434: 980-986.

[9] Epstein, E. 1999. Silicon Annual review of Plant Physiology and Plant Molecular Biology, 50: 641-664.

[10] Groth, D. and Hollier, C. (no date). Rice Blast Disease Management. Louisiana State University Agricultural Centre, Louisiana Cooperative Research and Extension Service.

[11] Hardter, R. 1997. Crop nutrition and plant health of rice based cropping systems in Asia. Agro-Chemicals News in Brief, 20 (4): 29-39.

[12] Hoffland, E., Beusichem, M.L., Jeger, M.J. 1999. Nitrogen availability and susceptibility of tomato leaves to Botrytis cinerea. Plant and Soil, 210: 263-272.

[13] Inanaga, S., Okasaka, A. and Tanaka, S. 1995. Does silicon exist in association with organic compounds in rice plant? Jpn. Journal of Soil Science and Plant Nutrition, 11: 111-117.

[14] Ishiguro, K. 1994. Using simulation models to explore better strategies for the management of blast disease in temperate rice pathosystems. pp. 435-450. Rice Blast Disease, Zeigler, R. S (ed.) IRRI, Los Banos, Philippines.

[15] Jensen, B. and Munk, L. 1997. Nitrogen induced changes in colony density and spore production of Erysiphe graminis f.sp.hordei on seedlings of six spring barley cultivars. Plant Pathology, 46: 191-202.

[16] Kapoor, A.S. and Sood, G.K. 2000. Effect of time of application and splitting of nitrogen on rice blast. Indian Phytopathology, 55: 283-286.

[17] Kato, Y., Satoshi, H., Akiniko, K., Abe, J., Urasaki, K. and Yamagishi, J. 2004. Enhancing grain yield of rice (Oryza sativa L.) under upland conditions in Japan. $4^{\text {th }}$ International Crop Science Congress, Brisbane, Australia.

[18] Kim, C. K. 1994. Blast management in high input, high yield potential, temperate rice ecosystems. In: Rice Blast Disease. Zeigler, R.S. and Leong, S.A. (eds.). CAB International, Wallingford, U.K.

[19] Kim, C.H. and Kim, C.K. 1990. Rice blast development under different water management practices in fields in Korea. Korean Journal of Plant Pathology, 6: 51-57.

[20] Kobayashi, T., Kanda, E., Kitada, K., Ishiguro, K., and Torigoe, Y. 2001. Detection of rice panicle blast with multispectral radiometer and the potential of using airborne multispectral scanners. Phytopathology, 91: 316-323.

[21] Korndorfer, G.H, Snyder, G.H. Ulloa, M, Powel, G. And Datnoff, L.E. 2001. Calibration of soil and plant silicon analysis for rice production. Journal of Plant Nutrition, 24 (7): 1071-1084.

[22] Koutroubas, S.D., Katsantonis, D., Ntanos, D.A., Lupotto, E. 2008. Nitrogen utilization efficiency and grain yield components of rice varieties grown under blast disease stress Australasian Plant Pathology, 37 : 53-59.

[23] Kurschner, E. Bonman, J.M., Garrity, D.P, Tamisin, M.M., Pabale, D. Estrada, B.A. 1992. Effects of nitrogen timing and split application on blast disease on upland rice. Plant Disease, St. Paul, 76: .384-389.

[24] Lea, P.J., Satok, L., Parry, M.A., Shewry, P. R., Halford, N. G. 2007. Asperagine in plants annuals of Applied biology, 150: 1-26

[25] Lee,Y.H. and Dean, R.A. 1993. AMP Regulates Infection Structure Formation in the Plant Pathogenic Fungus Magnaporthe grisea. The Plant, Cell 5: 693-700.

[26] Lee, F. N. 1994. Rice breeding programs, blast epidemics and blast management in the United States. Pp 489-500. In: Rice Blast Disease. Zeigler, R. S., Leong, S. and. Teng, P.S. (eds.) CAB International, Wallingford, UK.

[27] Leitch, M.H. and Jenkins, P.D. 1995. Influence of nitrogen on the development of Septoria epidemics in winter wheat. Journal of Agricultural Science, 124: 361-368.

[28] Long. D.H., Lee, F.N. and Tebeest, D.O. 2000 Effect of nitrogen fertilization on disease progress of rice blast on susceptible and resistant cultivars. Plant disease, 84: 403-409. 
[29] Luo, Y, Teng, PS, Fabellar, N.G. and Tebeest, D.O. 1998. Risk analysis of yield losses caused by rice leaf blast associated with temperature changes above and below for five Asian countries. Agriculture, Ecosystem and Environment, 68:197-205.

[30] Luong, M. C, Hoang, D C, Phan, T. B, Luong, T.P Jiaan, C. and Heong, K.L. 2003. Impacts of nutrition management on insect pests and diseases of rice. Omonrice, 11: 93-102.

[31] Magdoff, F. H., Van, E. 2000. Building soils for better crops. SARE, Washington DC.

[32] Ma, J. and Takahashi, E. 1991. Effect of silicate on phosphate availability for rice in a P-deficient soil. Plant and Soil, 133: 151-155.

[33] Manandhar, H.K., Lyngs, Jorgensen, H.J., Simegaardperterson, V. and Marthur, S.B. 1998. Seedborn infection of rice by Pyricularia oryzae and its transmission to seedlings. Plant Disease, 82: 1093-1099.

[34] Marschner, H. 1995. Beneficial mineral elements. Pp. ,435 - 406. In: Mineral Nutrition of Higher Plants. $2^{\text {nd }}$ edition. Academic Press, San Diego, CA.

[35] Massey, F.P. and Hartley, S.E 2006. Experimental demonstration of the anti-herbivore effects of silica in grasses: impacts on foliage digestibility and vole growth rates. Proc. R. Soc. B, 273: 2299-2304.

[36] Meyer, G.A. 2000. Interactive effects of soil fertility and herbivory on Brassica nigra. Oikos, 22: $433-441$.

[37] Netam, R.S., Bahadur, A.N., Tiwari, U. and Tiwari, R.K.S. 2011. Efficacy of plant extracts for the control of (Pyricularia grisea) Blast of Rice under Field condition of Bastar, Chattisgarh. Research Journal of Agricultural Science 2 (2): 269-271.

[38] Norman, R.J., Guindo D., Wells B.R., Wilson, C.E. 1992. Seasonal accumulation and partitioning of nitrogen in rice. Soil Science Society of America Journal 56: 1521-1527.

[39] NSW (State of New South Wales through the Department of Trade and Investment, Regional Infrastructure and Services). 2012. Exotic Pest Alert: Rice blast. www.dpi.nsw.gov.au/biosecurity/plant.

[40] Nyvall, R.F. 1999. Field Crop Diseases. Iowa State University Press, USA.

[41] Prabhu, A.S., Barbosa Filho, M.P., Fillippi, M.C., Datnoff, L.E. and Synder, G.H. 2001. Silicon from rice disease control perspective in Brazil. Pp 293-331. In: Silicon in Agriculture. Datnoff, L.E., Synder, G.H. and Korndorfer, G.H. (eds.) Studies in Plant Science, 8 Elsevier Science B.V., Amsterdam, the Netherlands.

[42] Rao, K.M. 1994. Rice Blast Disease. Daya Publishing House, Delhi, India.

[43] Robert, C., Bancal, M.O., Ney, B. and Lannon, C. 2005. Wheat Leaf Photosynthesis loss due to leaf rust with respect to lesion development and leaf nitrogen status. New pathologist, 165: 227-241.

[44] Rodrigues, F.A., Datnoff, L.E., Korndorfer, G.H., Seebold, K.W. and Rush, M.C. 2001. Effect of silicon and host resistance on sheath blight development in rice. Plant Dis. 85: 827-832.

[45] Roumen, E.C., 1992. Partial resistance to neck blast influenced by stage of panicle development and rice genotype. Euphytica. 64: 173-182.

[46] Savant, N.K., Snyder, G.H., and Datnoff, L.E. 1997. Silicon management and sustainable rice Press, production. Pp 151-199. In: Advances in Agronomy, 58: 151-199.

[47] Seebold, K.W., Datnoff. L.E., Corea -Victoria, F.J., Kucharek, T.A. and Snyder, G.H. 2000. Effect of Silicon Rate and Host Resistance on Blast, Scald, and Yield of Upland Rice. The American Phytopathological Society, Plant Disease, 84(8): 871-876.

[48] Seebold, K.W., Kucharek, T.A., Datnoff, L.E., Correa-Victoria, F.J. and Marchetti, M.A. 2001. The influence of silicon on components of resistance to blast in susceptible, partially resistant and resistant cultivars of rice. Phytopathology, 91: 63-69.

[49] Snoeijers, S.S., Perez-Garcia, A., Joosten, M.H., and De Wit, P.J. 2000. The effect of nitrogen on disease development and gene expression in bacterial and fungal plant pathogens. European Journal of Plant Pathology, 106: 493-506.

[50] Solomon, P.S., Tan, K.C, Oliver RP. 2003. The nutrient supply of pathogenic fungi; a fertile field for study. Molecular Plant Pathology, 4: 203-210.

[51] Tiedemann, A. 1996. Single and combined effects of nitrogen fertilization and ozone on fungal leaf diseases on wheat. Journal of Plant Diseases and Protection 103: 409-419.

[52] Thurston, H.D. 1998. Tropical plant diseases second edition. APS press. American phytopathological society, pp $31-40$.

[53] Vance, C.P., Kirk, K. and Sherwood, R.T. 1980. Lignifications as a mechanism of disease resistance. Annual. Review of Phytopathology, 18: 259-288.

[54] Webster, R.K. and Gunnell,P.S 1992. Rice blast. Pp. 14-17 In: Compendium of rice Diseases. Webster, R.K. and Gunnell, P.S. (eds.) Amercam phytopathological Society,St Paul,MN. 
[55] Webster, R.K. 2000. Rice Blast Disease Identification Guide. Department of plant pathology, University of California, Navis.

[56] Wilson, C.E. Norman, R.J., Wells, B.R. 1990. Dicyandiamide influence on uptake of pre-plant applied fertilizer nitrogen by rice. Soil Science Society of America Journal 54: 1151-1161.

[57] Zeigler, R.S, Leong, S.A and Teng, P.S. 1994. Rice blast disease. CAB International Mycological Institute, Kew.UK

[58] Zhou, E., Jia, Y., Singh, P., Correll, J.C. and Lee, F.N. 2007. Instability of the Magnaporthe oryzae avirulence gene AVR-Pita alters virulence. Fungal Genetics and Biology.

Citation: Desalegn Yalew Fetene, "Review of the Rice Blast Diseases (Pyricularia Oryzae) Response to Nitrogen and Silicon Fertilizers" International Journal of Research Studies in Agricultural Sciences (IJRSAS), 2019; 5(5), pp. 37-44, http://dx.doi.org/10.20431/2454-6224.0505005

Copyright: (c) 2019 Authors. This is an open-access article distributed under the terms of the Creative Commons Attribution License, which permits unrestricted use, distribution, and reproduction in any medium, provided the original author and source are credited. 